\title{
PENGAMBILAN KEPUTUSAN DAN KEPEMIMPINAN DALAM KEPERAWATAN
}

\author{
Safitri Nur Diana \\ Dhitanayu Cakrawardani
}

dianasaftr98@gmail.com

dhitaicha@gmail.com

Prodi Manajemen Fakultas Ekonomi dan Bisnis Universitas Narotama

\begin{abstract}
ABSTAK
Penelitian ini berkaitan dengan pola proses pengambilan keputusan yang diambil oleh perawat dan paramedis di rumah sakit swasta di Surakarta, Jawa Tengah. Proses pengambilan keputusan meliputi aspek fisik dan psikologis perawat dan paramedis dalam membantu pasien. Pengambilan keputusan mewakili proses pengambilan risiko yang tinggi karena berurusan dengan konsekuensi hidup dan mati, terutama dalam situasi darurat. Penelitian ini adalah penelitian kualitatif. Metode pengumpulan data meliputi observasi dan wawancara. Hasil penelitian menunjukkan bahwa perawat dan paramedis membuat keputusan mereka berdasarkan pengalaman mereka, termasuk norma, latar belakang pendidikan, dan rekomendasi keahlian. Gaya pengambilan keputusan fleksibel dan tegas.
\end{abstract}

Kata Kunci : pengambilan keputusan, perawat, paramedis 


\section{PENDAHULUAN}

Sebelum melangkah jauh sebaiknya perlu diketahui bahwa kepemimpinan dan manajemen adalah dua hal yang berbeda dari segi keterampilan dan kemampuan. Seorang manajemen merupakan seorang yang kompetan tetapi tidak selalu mengarah kearah baik, sebaliknya pemimipin mungkin tidak mahir dalam manajemen tatapi mengarahkan ke tujuan yang memberdayakan orang (Kantanen et al., 2017). Dalam mengartikan kepemimpinan sudah dijelaskan dalam Al-Qur'an, sehingga mendapatkan hasil yang tautan dengan pemimpin itu sendiri. Adapaun ayat dalam Al-Qur'an surat Al-Baqarah/2: 20, Artinya" Ingatlah ketika Tuhanmu berfirman kepada para Malaikat: "Sesungguhnya Aku hendak menjadikan seorang khalifah di muka bumi". Mereka berkata: "Mengapa Engkau hendak menjadikan (khalifah) di bumi itu orang yang akan membuat kerusakan padanya dan menumpahkan darah, padahal kami senantiasa bertasbih dengan memuji Engkau dan mensucikan Engkau?" Tuhan berfirman: "Sesungguhnya Aku mengetahui apa yang tidak kamu ketahui".

Kepemimpinan merupakan kemampuan yang dimiliki seseorang dalam mempengaruhi orang lain untuk menjadi pengikutnya. Setiap pemimpin memiliki gaya kepemimpinan berbeda-beda, setiap pemimimpin memiliki cara sendiri dalam memimpin organisasinya untuk mencapai tujuan yang sudah ditentukan. Peran pemimpin yang efektif mampu menyusun strategi kedepan dan berpandangan jauh, mengembangkan diri, kritis, mampu menyelesaikan masalah, menghormati antar individu dan mempunyai keterampilan komunikasi dan pendengar bagi orang lain. Fungsi kepemimpinan adalah membimbing, menjalin komunikasi baik dan melakukan pengawasan, pengorganisasian menuju tujuan yang sudah ditetapkan (Mugianti, 2016).

Kepemimpinan yang efektif dalam keperawatan merupakan hal yang sangat penting, kepemimpinan dibidang keperawatan sangat penting karena merupakan disiplin ilmu yang luas dalam sistem keperawatan kesehatan (Lorber et al., 2016). Perawat selalu ditantang untuk berpikir tentang kepemimpinan terutama dalam masalah perubahan kesehatan yang sangat cepat dan menentukan tindakan yang tepat. Perawat yang mengetahui gaya kepemimpinan sangat berguna untuk meningkatkan kinerja staff perawat dan meningkatkan pelayanan yang aman serta efektif (Cope, Vicki; Murray, 2017).

Kehidupan manajer dipenuhi dengan serangkaian pembuatan keputusan. Kegiatan ini memainkan peranan penting, karena kualitas keputusan - keputusan manajer akan menentukan efektifitas rencana yang disusun. Secara umum, pengertian pengambilan keputusan telah dikemukakan oleh banyak ahli.Pengambilan keputusan adalah pemilihan alternatif perilaku (kelakuan) tertentu dari dua atau lebih alternatif yang ada (George R. Terry, 2001). Sedangkan

menurut S.P. Siagian, Pengambilan keputusan adalah suatu pendekatan yang sistematis terhadap hakikat alternatif yang dihadapi dan mengambil tindakan yang menurut perhitungan merupakan tindakan yang paling tepat. 
Pengambilan keputusan merupakan proses yang kompleks yang memerlukan penanganan yang serius. Secara umum, proses pengambilan keputusan meliputi tujuh langkah berikut (Gibson dkk, 1987)

1. Menerapkan tujuan dan sasaran : Sebelum memulai proses pengambilan keputusan, tujuan dan sasaran keputusan harus ditetapkan terlebih dahulu. apa hasil yang harus dicapai dan apa ukuran pencapaian hasil tersebut.

2. Identifikasi persoalan : Persoalan-persoalan di seputar pengambilan keputusan harus diidentifikasikan dan diberi batasan agar jelas. Mengidentifikasikan dan memberi batasan persoalan ini harus tepat pada inti persoalannya, sehingga memerlukan upaya penggalian.

3. Mengembangkan alternatif : Tahap ini berisi pengidentifikasian berbagai alternatif yang memungkinkan untuk pengambilan keputusan yang ada. Selama alternatif itu ada hubungannya, walaupun sedikit, harus ditampung dalam tahap ini. Belum ada komentar dan analisis.

4. Menentukan alternatif : Dalam tahap ini mulai berlangsung analisis tehadap berbagai alternatif yang sudah dikemukakan pada tahapan sebelumnya. Pada tahap ini juga disusun juga kriteriatentang alternatif yang sesuai dengan tujuan dan sasaran pengambilan keputusan. Hasil tahap ini mungkin masih merupakan beberapa alternatif yang dipandang layak untuk dilaksanakan.

5. Memilih alternatif : Beberapa alternatif yang layak tersebut di atas harus dipilih satu alternatif yang terbaik. pemilihan alternatif harus harus mempertimbangkan ketersediaan sumberdaya, keefektifan alternatif dalam memecahkan persoalan, kemampuan alternatif untuk mencapai tujuan dan sasaran, dan daya saing alternatif pada masa yang akan datang.

6. Menerapkan keputusan : Keputusan yang baik harus dilaksanakan. Keputusan itu sendiri merupaka abstraksi, sedangkan baik tidaknya baru dapat dilihat dari pelaksanaannya.

7. Pengendalian dan evaluasi : Pelaksanaan keputusan perlu pengendalian dan evaluasi untuk menjaga agar pelaksanaan keputusan tersebut sesuai dengan yang sudah diputuskan.

Kepemipinan dalam organisasi adalah sebuah proses dimana seorang pemimpin memengaruhi dan memberikan contoh kepada pengikutnya dalam upaya mencapai tujuan organisasi. Pemimpin yang baik bukan dilihat dari seberapa banyak orang yang menjadi pengikutnya, bukan juga dilihat dari seberapa lama ia memimpin. Pemimpin yang baik dilihat dari seberapa banyak ia mampu menciptakan sosok pemimpin yang baru. Kepemimpinan menjadi salah satu faktor penting bagi keberhasilan sebuah organisasi. Untuk itu, ada beberapa sikap kepemimpinan dalam organisasi yang perlu diterapkan oleh seorang pemimpin, diantaranya:

1. Menjalin kedekatan dengan anak buah Kepemimpinan dalam organisasi akan menjadi lebih efektif jika seorang pemimpin telah mendapat respek dari anak buah. Hal ini bisa dibangun dengan menjalin kedekatan dengan mereka, sehingga mereka akan percaya dan mau mengikuti arahan Anda. 
2. Memberikan semangat dan motivasi Kepemimpinan dalam organisasi bukan melulu soal pangkat dan jabatan, tetapi kepemimpinan adalah bagaimana seorang pemimpin dapat memberikan semangat dan motivasi, bahkan untuk setiap hal kecil dari pekerjaan yang anak buah Anda lakukan.

3. Memberikan kepercayaan dan tanggung jawab Kepemimpinan dalam organisasi adalah tentang kepercayaan. Berikan anak buah Anda kepercayaan dan tanggung jawab yang lebih dalam melakukan tugas mereka. Jika ada hal yang tidak sejalan, jangan langsung menghakimi. Berikanlah feedback agar ke depannya mereka tidak takut salah dalam mengambil sebuah keputusan.

Pengambilan keputusan dalam penyelesaian masalah adalah kemampuan mendasar bagi praktisi kesehatan, khususnya dalam asuhan keperawatan dan kebidanan. Tidak hanya berpengaruh pada proses pengelolaan asuhan keperawatan dan kebidanan, tetapi penting untuk meningkatkan kemampuan merencanakan perubahan. Perawat dan bidan pada semua tingkatan posisi klinis harus memiliki kemampuan menyelesaikan masalah dan mengambil keputusan yang efektif, baik sebagai pelaksana/staf maupun sebagai pemimpin.

Penyelesaian masalah dan pengambilan keputusan bukan merupakan bentuk sinonim. Pemecahan masalah dan proses pengambilan keputusan membutuhkan pemikiran kritis dan analisis yang dapat ditingkatkan dalam praktek. Pengambilan keputusan merupakan upaya pencapaian tujuan dengan menggunakan proses yang sistematis dalam memilih alternatif. Tidak semua pengambilan keputusan dimulai dengan situasi masalah.

Pemecahan masalah termasuk dalam langkah proses pengambilan keputusan, yang difokuskan untuk mencoba memecahkan masalah secepatnya. Masalah dapat digambarkan sebagai kesenjangan diantara "apa yang ada dan apa yang seharusnya ada". Pemecahan masalah dan pengambilan keputusan yang efektif diprediksi bahwa individu harus memiliki kemampuan berfikir kritis dan mengembangkan dirinya dengan adanya bimbingan dan role model di lingkungan kerjanya. 
Metode reflektif di dalam praktek keperawatan bukan merupakan hal yang baru digunakan oleh perawat di seluruh negara, metode reflektif dalam keperawatan mampu meningkatkan kemampuan berpikir kritis dan menjadi problem solving sehingga perawat dalam melakukan asuhan keperawatan secara aman dan kompeten. Dalam putusan Menkes RI No.836/Menkes/SK/VI/2005 yang mengatur tentang pedoman pengembangan manajemen perawat bahwa para tenaga keperawatan disarankan melakukan Diskusi Refleksi Kasus (DRK) untuk merefleksikan pengalaman klinis mereka. Pembelajaran dengan metode reflektif merupakan kegiatan yang dilakukan untuk mengingat kembali suatu kejadian yang pernah terjadi dalam bentuk observasi. Refleksi melakukan pengajian ulang terhadap kejadian yang terjadi dengan mempertimbangkan proses, masalah isu dan belum tercapainya tujuan dari strategi yang telah dilakukan.

Metode ini menjadi dasar untuk mengetahui kembali rencana tindakan dengan melihat variasi prespektif yang memiliki aspek evaluatif dalam mempertimbangkan dampak dan hasil yang didapat dimasa depan. Faktor pengalaman juga berpengaruh pada tingkat refleksi kasus, hasil tersebut didukung oleh (Okamoto et al., 2017) bahwa pengalaman perawat berhubungan dengan keterampilan praktis mereka. Pembelajaran reflektif ini dapat mencegah perawat dalam terjebak pada asumsi, kebiasaan dan rutinitas yang tidak dapat meningkatkan professional perawat (Dubé and Ducharme, 2015).

Salah satu faktor yang mempengaruhi mutu pelayanan kesehatan adalah cara kepemimpinan kepala ruangan (Pratiwi et al., 2016). Untuk menciptakan mutu pelayanan yang baik berbagai teori refleksi kasus dan gaya kepemimpinan telah dikembangkan dan dapat digunakan, sedikitya ada beberapa metode pendekatan refleksi kasus seperti menggunakan alur refleksi John, model refleksi Atkinson dan Murphy ,model refleksi Gibbs dan model refleksi Driscoll. Dan beberapa gaya kepimpinan yang dapat diaplikasikan dalam pelayanan seperti kepemimpinan seperti menurut Likert, teori X dan Y, Robert House, Hersey dan Blanchard, dan Lippits dan K.White.

Masalah yang terjadi saat ini adalah seringnya perawat tidak menyadari bahwa mereka menerapkan suatu teori kepemimpinan tetapi tidak tahu batasan yang diterapkan, misalnya dalam situasi gawat darurat perawat mengambil alih sebagai pemimpin, padahal perawat tidak diminta secara formal tetapi dapat mengarahkan tim yang terlibat. Dalam situai tersebut pentingnya memahami konsep kepemimpinan dan pengaruhnya terhadap pelayanan keperawatan.

\section{A. Pengertian Kepemimpinan Islam}

Kepemimpinan islam sudah dijelaskan dalam al-quran, terdapat 3 definisi pemimpin diantaranya khalifah, Imāmah, dan Ūlu al-Amr. Khalifah merupakan penganti nabi Muhammad SAW untuk memimpin umat islam mengadakan perubahan untuk lebih maju mensejahterakan umat dengan tetap menganut nilai-nilai islami. Imāmah mulanya berarti pemimpin dalam shalat, tetapi dapat diartikan sebagai panutan yang membimbing orang lain. dan Ūlu al-Amr dapat 
dijelaskan sebagai "pemilik kekuasaan" atau "pemilik urusan" dalam hal ini menjelaskan bahwa orang yang berhak mengatur suatu urusan dan mengendalikan keadaan.

Sifat-sifat kepemimpinan yang efektif diantaranya mempunyai sifat bertakwa kepada Allah SWT, amanah, shiddiq, fathonah, tabligh, tegas dan teguh dalam pendirian, lemah lembut, pemaaf, senang bermusyawarah, bertawakal kepada Allah, adil, sabar dan bertanggung jawab. Berkenaan dengan kriteria kepemimpinan disebutkan dalam ayat Al-Quran yaitu: QS. al-Anbiyā' (21): 73 artinya "kami telah menjadikan mereka itu sebagai pemimpin-pemimpin yang memberi petunjuk dengan perintah Kami dan telah Kami wahyukan kepada mereka mengerjakan kebajikan, mendirikan sembahyang, menunaikan zakat, dan hanya kepada Kamilah mereka selalu menyembah". Ayat tersebut menjelaskan bahwa setiap orang adalah pemimpin baik memimpin orang lain maupun memimpin untuk dirinya sendiri. QS. al-Nisa (4): 59 Artinya "Hai orang-orang yang beriman, ta'atilah Allah dan ta atilah Rasul (Nya), dan ulil amri di antara kaтu. Kemudian jika kamu berlainan pendapat tentang sesuatu, maka kembalikanlah ia kepada Allah (Al Qur'an) dan Rasul (sunnahnya), jika kamu benar-benar beriman kepada Allah dan hari kemudian. Yang demikian itu lebih utama (bagimu) dan lebih baik akibatnya"

\section{B. Pengertian Kepemimpinan}

Konsep pemimpin dan menajeman merupakan istilah yang digunakan secara sinonim, namun berbeda. Perbedaannya pemimpin tidak selalu ditunjuk oleh seseorang, mungkin tidak menjadi bagian organisasi secara hararki, tujuannya memberdayakan orang dan menekankan pada hubungan interpersonal (Cope, Vicki; Murray, 2017). Kepemimpinan adalah unsur terpenting dan merupakan penentu kelancaran sistem pelayanan di rumah sakit, karena kepimimpinan inti dari manajemen organisasi sehingga aktifitas kepemimpinan menunjukan pola gaya memimpin yang berbeda-beda (Harahap, 2016). Menurut Nursalam, (2014)kompetensi yang harus dimiliki oleh manajer keperawatan dalam meningkatkan kepemimpinannya pada abad 21 memiliki 7 kategori yaitu: 1.Kepemimpinan, 2.Perencanaan dan pengambilan keputusan, 3.Hubungan masyarakat/komunikasi, 4.Anggaran, 5.Pengembangan, 6.Personalitas, 7.Negosiasis.

Sebagai perawat dituntut memiliki kiat dan strategi dalam menyelesaikan program yang dipenagaruhi oleh pergantian atau perubahan dalam organisasi sehingga pendekatan adalah suatu harga (PRICE) P: Pinpoint yaitu menentukan area kinerja, R: Record yaitu mengukur kinerja, I: Involve yaitu sepakat dengan tujuan dan stategi yang akan ditetapkan, C: Coach yaitu mengamati kinerja dan mengelola tanggung jawab, E: Evaluate yaitu evalusi kinerja dan 
menentukan arah kedepan. Kepemimpinan yang efektif diterapkan oleh kepala ruang akan mempengaruhi perawat dalam menerapkan budaya dan motivasi dalam keselamatan pasien (Pratiwi et al., 2016).

\section{Macam-Macam Teori Kepemimpinan :}

Di era globalisasi sekarang teori kepemimpinan sudah banyak dikembangankan dan dapat diaplikasikan, berikut pengembanga teori menurutNursalam, (2014) yaitu:

a) Trait Theory (Teori Bakat)

Penjelasan teori ini bahwa setiap orang adalah pemimpin (yang dibawa sejak lahir) yang mempunyai karakteristik tertentu yang membuat lebih baik dari pada orang lain. Teori ini memiliki karakteristik tentang intelegensi, personalitas dan kemampuan.

b) Teori Perilaku

Teori ini menekankan apa yang dilakukan pemimpin dan bagaimana pemimpin menjalankan fungsinya, teori ini dalam rentang antara perilaku otoriter ke demokratis atau awalnya fokus pada suatu produksi ke fokus pegawai.

c) Teori Kontingensi Dan Situasional

Teori yang menekankan bahwa melaksanakan tugasnya dengan mengombinasikan antara faktor bawaan, perilaku dan situasional. Unsur utama manajer adalah kemampuan dalam manajer dan penghargaan terhadap kelompok. hubungan antara kelompok manajer dan pegawai merupakan hal penting sehingga penerapan gaya kepemimpinan situasional yang paling tepat.

d) Teori Kontemporer

Teori menggunakan 4 komponen penting dalam pengolahannya, seperti manajer/pemimpin, staf dan atasan, pekerjaan, serta lingkungan. Dalam menerapkan teori ini harus menerapkan 4 komponen tersebut dan perlu didukung dengan teori motivasi, interaksi dan transformasi.

e) Teori Motivasi

Teori yang dikemukakan oleh beberapa ahli seperti Maslow, Aldefer, Herzberg, McCelland, Adams, dan V. Vroom. Berdasarkan isinya terbagi menjadi teori Hierarki kebutuhan, ERG, Teori dua faktor, teori 2 faktor. Berdasar proses diantaranya teori keadilan, harapan, penguatan dan teori belajar. Berdasar masalah motivasi diantaranya pembagian tugas tidak jelas, hambatan dalam pelaksanaan, kurangnya penghargaan dan kurangnya dukungan organisasi.

f) Teori Z 
Teori yang dikenalkan oleh Ouchi (1981) merupakan pengembangan dari teori Y (McGregor, 1460) yang mendukung gaya kepemimpinan demokratis. Komponen teori mencakup pengambilan keputusan dan kesepakatan, menempatkan sesuai keahlian, menekankan keamanan pekerjaan, promosi yang lambat dan pendekatan secara holistic kepada staff.

g) Teori Interaktif

Teori bahwa manusia sebagai suatu sistem yang terbuka dan selalu berinteraksi dengan sekitar dan berkembang secara dinamis. Asumsi teori mencakup 1. Manusia memiliki karakteristik yang kompleks 2. Motivasi berkembang sesuai perubahan waktu 3. Tujuan berubah disaat perubahan situasi 4 . Produktifitas dipengaruhi oleh penyelelesaian tugas 5. Tidak ada strategi efektif bagi pemimpin dalam situasi tertentu.

\section{Gaya Kepemimpinan}

a) Menurut para ahli terdapat beberapa gaya yang ditetapkan pemimpin di suatu organisasi seperti menurut Tannenbau dan Warrant H. Schmitdt, Likert, teori X dan Y, Robert House, Hersey dan Blanchard, Lippits and K. White, dan menurut Gillies (Nursalam, 2014). Berikut gaya kepemimpinanmenurut Lippits dan K. White yang dibagi menjadi 3 gaya:

1) Gaya Kepemimpinan Otoriter

Gaya pemimpin yang kewenangan, keputusan, kebijakan mutlak berada pada pemimpin. Komunikasi dari pemimpin ke bawahan, pengawasan seperti sikap, tingkah laku perbuatan diawasi dengan ketat. Tidak ada kesempatan bawahan untuk memberikan saran, pertimbangan. Lebih banyak kritik dan menuntut pada kesempurnaan serta kesetiaan tanpa syarat. Cenderung dengan menggunakan ancaman dengan sikap yang kasar.

2) Gaya Kepemimpinan Demokratis

Gaya yang dapat mempengaruhi orang lain agar bersedia bekerja sama untuk mencapai tujuan yang telah ditentukan. Ciri-ciri kepemimpinan demokratis adalah kewenangan tidak mutlak dari pemimpin, sebagian kewenangan dilimpahkan ke bawahan, keputusan dibuat secara kesepakatan bersama, komunikasi dan pengawasan secara baik dan wajar, banyak kesempatan bawahan untuk menyampaikan saran, pemimpin mendorong prestasi bawahan sesuai batasan dan terdapat rasa saling percaya, menghormati dan menghargai.

3) Gaya Kepemimpinan Liberal/Laissez Faire

Yaitu kemampuan mempengaruhi orang lain agar bekerja sama mencapai tujuan dengan lebih banyak menyerahkan pelaksanaan kegiatan kepada bawahan. Ciri kepemimpinan ini adalah 
kewenangan, keputusan, kebijaksannan lebih banyak dilimpahkan ke bawahan, komunikasi atasan dan bawahan apabila diperlukan, hampir tidak ada pengawasan terhadap bawahan. Kepentingan pribadi lebih penting dari pada kelompok dan tanggung jawab keberhasilan dipikul oleh perorangan.

b) Selain gaya tersebut ada beberapa gaya kepemimpinan yang dapat diterapkan di dalam pelayanan keperawatan, gaya tersebut sebagian besar dibagi menjadi kepemimpinan relasional dan kepemimpinan berfokus pada tugas, berikut gaya kepemimpinan yang dapat diaplikasikan (Cope, Vicki; Murray, 2017):

1) Kepemimpinan Relasional

Kepemimpinan yang berfokus pada orang dan hubungan, berhubungan dengan kepuasan staff, komitmen organisasi, kesehatan dan kesejahteraan staff, pengurangan stress, kepuasan kerja, kerja efektif dan hasil efektif.

a) Transformasional

Pusat keperawatan pada keperawatan karena terdapat budaya kesehatan, kepuasan staff dan hasil pasien. Pemimipin memotivasi dan pemberdaaan serta menginspirasi dengan mengidentifikasi dan mengejar visi jangka panjang yang berkaitan dengan tujuan organisasi dan karir individu perawat. Menggunakan pendekatan demokratis dan berbagi tanggung jawab dengan anggotanya. Mendapatkan kepercayaan dengan hubungan mendengarkan, menangapi dan berempati dengan anggota.

b) Kecerdasaan Emosional

Mempunyai 4 konsep yaitu: kesadaran diri, kesadaran sosial, manajemen diri serta keterampilan sosial. Pemimipin yang cerdas emosi sensitive terhadap kesejahteraan, perasaaan dan kesehatan sosial dan kemudian mengembangkan hubungan efektif untuk mengarahkan anggotanya. Mampu membuat keputusan yang rasional untuk melakukan perubahan dan kerjasama untuk melahirkan kerjasama tim/kolaborasi. Konsep ini paling efektif menyelesaikan masalah karena kemampuan melihat situasi dari mata orang lain dalam mengelola stress kerja.

c) Kepemimipinan Rensonan

Konsep yang didasarkan pada kecerdasan emosional dan kesadaan, proses mendekati masaalah dengan fokus pada sikap terbuka dan tanpa penghakiman. Pemimipin yang berusaha memberdayakan dengan meningkatkan percaya diri anggota, membangun kepercayaan dan dengan emosi yang selaras pada organisasi. Memiliki artribut kecerdasan emosional kesadaran 
diri, kesadaran sosial, manajemen diri serta manajemen hubungan yang berarti efektif jika terjadi konflik dan mempu menyelesaikan masalah dengan demokrasi.

d) Kepemimpinan Parsitipasif

Konsep yang menghargai pengetahuan, pengalaman, pendapat individu dalam memutuskan keputusan. Gaya ini didasarkan rasa hormat dan melibatkan masyarakat secara luas dan efektif dalam mengoptimalkan kekuatan dari prespektif orang banyak untuk mengatasi tantangan dalam organisasi.

e) Kepemimpinan Otentik

Definisi konsep ini adalah sikap pola perilaku pemimimpin yang transparan dan etis dalam keterbukaan dalam berbagai informasi yang dibutuhkan dan menerima masukan-masukan dalam membuat keputusan. Pemimpin ini memiliki 4 komponen yakni kesadaran diri, proses yang seimbang, diinternalisasi dan transparansi relasional dan sudah terbukti dapat meningkatkan kolaborasi di pelayanan kesaehatan (Regan et al., 2016)

2) Kepemimpinan Berfokus Pada Tugas

a) Kepemimipinan Transaksional Dan Otokratis

Kemimipinan transaksional biasanya tujuan bersifat jangka pendek, terdapat hadiah untuk menyelesaikan tugas sehingga menyebabkan motivasi pada pengikut. Kepemimipinan ini efektif dalam pengaturan bisnis tetapi tidak dalam keperawatan karena menyebabkan pendekatan saaat perawatan pasien berfokus pada penyelesaian tugas saja. Bentuk transaksional adalah kepemimipinan otokratis dimana berorientasi pada pengendalian dan close-minded sehingga menuntut pada ketaatan, kesetiaan dan ketaatan pada aturan, keuntungan para pemimipin ini adalah mempromosikan struktur dan memprioritaskan kebutuhan.

b) Kepemimipinan Laissez-Faire

Model yang berfokus pada tugas kepemimipinan pada saat terjadi krisis. Pendekatan konsep "lepas tangan" dengan meninggalkan keputusan kepada orang lain, biasanya model ini dipakai karena hendak mengkosongkan posisi sehingga keputusan mengarah pada orang lain atau orang yang mengantikannya. Namun jika anggota yang mampu memotivasi diri sendiri dan sangat kompeten, tingkat pendekatan kebebasan menyebabkan hasil yang bagus (Vann et al., 2014).

c) Kepemimpinan Instrumental

Kepimimpinan ini berfokus memilih strategi yang cocok bersama dengan sumber daya yang tepat, dalam mencapai tujuan. Konsep ini berada diantara konsep kepemimipinan 
transformasional dan transaksional. Pemimipin mengambil gambar besar dari konsep transformasional dan fokus gambar kecil dengan masalah yang terjadi di lingkungan kerja. Pemimpin ini efektif dalam manjemen karena mempertahankan produktifitas anggotanya sehingga tugas dalam organisasi dapat diselesaikan.

\section{Reflective Cycle}

Reflektif merupakan belajar dari pengalaman, dengan mengingat serta mengevaluasi untuk meningkatkan pengetahuan praktek masa depan (Husebø et al., 2015). Makalah ini akan membahas menggunakan alur refleksi dengan menggunakan Model Gibbs. Model Gibbs ini mempunyai 6 tahapan, yaitudescription, feelings, evaluation, analysis, coclusion, dan action plan (Bulman and Schutz, 2013).

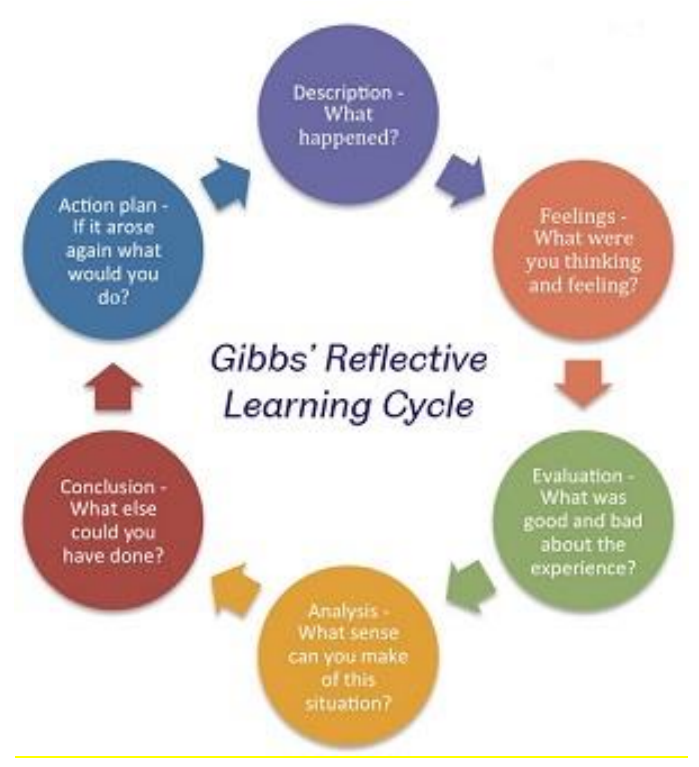

Gambar 1. Gibs Reflective Cycle

\section{1) Description}

Pada tahapan ini merupakan deskripsi dari pengalaman. Menjelaskan dengan detil pengalaman yang akan direfleksikan termasuk: dimana Anda saat kejadian, siapa lagi yang terlibat/ada di situ, mengapa Anda ada disitu, apa yang Anda lakukan, apa yang orang lain lakukan, dalam konteks apa pengalaman tersebut terjadi, apa yang terjadi, apa peranan Anda dalam pengalaman ini dan apa peranan orang lain yang ada di situ, apa hasil dari pengalaman itu.

\section{2) Feelings}

Identifikasi dan telaah reaksi, perasaan dan pikiran yang muncul dan Anda rasakan saat kejadian. Cobalah untuk jujur mengenai apa yang anda rasakan dan pikirkan meskipun hal ini 
mungkin tidak mudah.Cobalah untuk mengingat dan mengeksplorasi apa yang terjadi di dalam pikiran anda, Termasuk : bagaimana anda merasa ketika kejadian ini terjadi, apa yang anda pikirkan saat itu, bagaimana perasaan anda, bagaimana perasaan orang lain, bagaimana perasaan anda dari apa yang terjadi, apa yang anda pikirkan tentang hal itu sekarang.

\section{3) Evaluation}

Mengevaluasi atau membuat keputusan tentang apa yang telah terjadi, Pertimbangkan apa yang baik tentang pengalaman dan apa yang buruk tentang pengalaman.

4) Analysis

Melakukan analisis terhadap situasi ini. Ide-ide di luar pengalaman dapat digunakan sebagai pengalaman untuk membantu.

\section{5) Conclusion}

Kesimpulan dari pengalaman dan analisis yang telah dilakukan.

\section{6) Action plan}

Melakukan yang berbeda pada situasi semacam ini dan ketika waktu berikutnya apa yanag akan dilakukan. Langkah-langkah apa yang dapat diambil atas dasar apa yang telah dipelajari.

\subsection{Rumusan Masalah}

Rumusan masalah penulisan makalah ini yaitu untuk merefleksikan penyelesaian kasus disesuaikan dengan gaya kepemimpinan dengan menggunakan metode reflevtive learning.

1. Apa yang dimaksud dengan sistem pelayanan kesehatan?

2. Bagaimana sistem pelayanan kesehatan?

3. Apa saja tingkat pelayanan kesehatan?

4. Bagaimana lembaga pelayanan kesehatan?

5. Apa saja lingkup sistem pelayanan kesehatan?

6. Bagaimana pelayanan keperawatan dalam pelayanan kesehatan?

7. Faktor apa saja yang mempengaruhi pelayanan kesehatan?

\subsection{Tujuan Penelitian}

Tujuan secara umum :

1. Mengetahui cara menyelesaikan kasus dengan menggunakan metode reflective learning diterapkan dengan gaya kepemimpinan seseorang.

Tujuan Khusus : 
1. Mengetahui teori kepemimpinan dan gaya kepemimpinan

2. Mengetahui alur reflektive learning menggunakan model Gibbs reflective cycle

3. Merefleksikan penyelesaian kasus dengan menggunakan model Gibbs reflective cycle disesuaikan dengan gaya kepemimpinan.

\subsection{Manfaat Penelitian}

Penelitian ini diharapkan bermafaat baik secara teoritis maupun secara praktis. Pengaruh Kepememilikan penelitian ingin membuktikan secara empiris mengenai pengaruh kebijakan dan pengambilan keputusan dalam suatu lembaga atau instansi yang masih aktif. 


\section{BAB II}

\section{TINJAUAN PUSTAKA}

\subsection{Pengartian Kebijakan dan Pengambilan Keputusan}

\subsubsection{Pengertian Kebijakan}

Menurut Ahmad Sabri yang berjudul Kebijakan Dan Pengambilan Keputusan Dalam Lembaga Pendidikan Islam menyatakan, Manusia sebagai makhluk individu dan juga makhluk sosial senantiasa dihadapkan kepada berbagai persoalan atau masalah yang dijumpai hampir di setiap sisi kehidupannya. Semua bentuk persoalan atau masalah tersebut menuntut adanya pengambilan keputusan yang tepat dari sejumlah alternatif pemecahan agar semua yang direncanakan dapat tercapai secara optimal. Begitu pula halnya posisi dan kedudukan seseorang, baik dalam organisasi maupun lembaga, terkait dengan tugas-tugas dan tanggungjawab yang harus dilaksanakan, seringkali pula dihadapkan kepada kebijakan-kebijakan dan keputusan-keputusan yang harus diambil secara tepat agar roda organisasi beserta administrasinya dapat berjalan dengan baik dan lancar. Kebijakan dan pengambilan keputusan dalam lembaga pendidikan Islam secara substantif tidak terlalu jauh berbeda dengan teori-teori kebijakan dan pengambilan keputusan yang ada. Hanya saja kebijakan dan pengambilan keputusan dalam pendidikan Islam lebih mengacu kepada prinsip-prinsip yang telah digariskan dalam al-Quran dan hadis Nabi SAW.

\subsubsection{Pengertian Keputusan}

Menurut Raihan yang berjudul Pengambilan Keputusan Dalam Kepemimpinan Manajemen Dakwah menyatakan bahwa, Keputusan berarti hasil akhir dalam mempertimbangkan sesuatu yang akan dilaksanakan secara nyata. Keputusan dapat diartikan sebagai hasil terbaik dalam memilih satu dari lebih alternatif pilihan. Pengambilan keputusan merupakan proses rangkaian kegiatan menganalisis berbagai fakta, informasi, data dan teori/pendapat yang akhirnya 
sampai pada satu kesimpulan yang dinilai paling baik dan tepat. Secara umum, proses pengambilan keputusan kepemimpinan dapat melalui tiga tahap yaitu tahap penelitian, desain dan pemilihan. Sedangkan bila ditinjau dari tingkatan kepemimpinan manajemen dakwah, terdapat tiga tingkatan keputusan yang terdapat dalam suatu kepemimpina organisasi, yaitu keputusan strategik, keputusan teknis dan keputusan operasional. Kepemimpinanmanajemen dakwah memiliki hubungan erat dengan proses pengambilan keputusan.

\subsection{Jenis - jenis Pengambilan Keputusan}

Jenis-jenis pengambilan keputusan dilihat dari personal yang melakukan-nya dapaat dibagi kepada dua, yaitu: keputusan individual dan keputusan kelompok. Keputusan individual merupakan pengambilan keputusan yang dilakukan oleh pemimpin atau manajer secara sendiri, sedangkan keputusan kelompok adalah keputusan yang dibuat oleh sekelompok orang berdasarkan hasil musyawarah mufakat. Pengambilan keputusan secara kelompok dapat pula dibedakan kepada beberapa bentuk yaitu: (1) sekelompok pimpinan, (2) sekelompok orang-orang bersama pimpinannya dan (3) sekelompok orang yang mempunyai kedudukan sama dan keputusan kelompok. Beberapa kebaikan dari pengambilan keputusan secara kelompok adalah: (1) keputusan dapat lebih cepat ditentukan atau diambil karena tidak perlu menunggu persetujuan dari rekan lainnya, (2) memperkecil kemungkinan terjadinya pertentangan pendapat dan (3) jika pimpinan atau manajer yang mengambil keputusan itu memiliki kemampuan yang tinggi dan berpengalaman luas dalam bidang yang akan diputuskan, maka keputusannya berkemungkinan besar tepat.

\subsection{Tahap - tahap Pengambilan Keputusan}

\section{METODOLOGI PENELITIAN}

\section{HASIL PENELITIAN DAN PEMBAHASAN}


KESIMPULAN DAN REKOMENDASI 


\section{DAFTAR PUSTAKA}

Manajemen Pengambilan Keputusan, Endra Yuda

https://feelinbali.blogspot.com/2013/09/manajemen-pengambilan-keputusan.html

Kepemimpinan Dalam Organisasi, Kubik Leadership

https://www.kubikleadership.com/kepemimpinan-dalam-organisasi/

https://www.academia.edu/31382710/KEBIJAKAN_DALAM_KESEHATAN_DAN_KEPERA

WATAN

http://endratkartiko.blogspot.com/2018/01/teori-kepemimpinan-keperawatan.html 